\title{
Do princípio da proporcionalidade e sua aplicação no mandado de detenção europeu
}

\author{
The principle of proportionality and its application \\ in the European arrest warrant
}

\section{Túlio Felippe Xavier Januário ${ }^{1}$}

\author{
Mestrando em Direito pela Universidade de Coimbra/Portugal \\ tuliofxj@gmail.com \\ lattes.cnpq.br/1894712298793127 \\ orcid.org/0000-0003-0400-1273
}

\begin{abstract}
Resumo: Objetiva-se, com o presente trabalho, analisar a possibilidade e eventual necessidade de aplicação de um teste de proporcionalidade a ser realizado pelo Estado de execução, no âmbito do mandado de detenção europeu, como medida de contenção à utilização deste instrumento em casos de criminalidade não considerada grave. Para tanto, serão analisados, inicialmente, o princípio do reconhecimento mútuo e o seu preceito básico, qual seja, a ideia da confiança mútua entre os Estados-Membros da União Europeia, a fim de examinar o contexto da construção do espaço europeu de liberdade, segurança e justiça, assim como os pilares da criação do mandado de detenção. Feito isso, será possível diagnosticar o problema que ora se discute, qual seja, o da sua excessiva utilização para a chamada criminalidade menos grave, assim como averiguar suas possíveis soluções, dentre as quais, a possibilidade de controle por parte do Estado de execução.

Palavras-Chave: Reconhecimento mútuo; Confiança mútua; Mandado de detenção europeu; Princípio da proporcionalidade.
\end{abstract}

1 Mestrando em Direito pela Universidade de Coimbra. Bacharel em Direito pela Universidade Estadual Paulista "Júlio de Mesquita Filho" (UNESP). Pesquisador financiado pelo programa "ERASMUS+" na Georg-August-Universität Göttingen - Alemanha. Advogado. 
ABSTRACT: The aim of the present essay is to analyze the possibility and eventual necessity of a proportionality test to be accomplished by the executor state, in the scope of the European arrest warrant, as a manner to contain the use of it in cases of less serious crimes. Therefore, we will analyze, initially, the principle of mutual recognition and its basic precept, which is the idea of mutual trust between the Member States, to examine the context of the construction of the European space of freedom, security and justice, as well as the pillars of the creation of the arrest warrant. That being said, it will be possible to diagnose the problem that we are now discussing, which is, the excessive utilization of the instrument to less serious crimes, as well as try to find out possible solutions, among which, the possibility of a control by the Executor State.

KeYwords: Mutual recognition; Mutual trust; European Arrest Warrant; Principle of proportionality.

Sumárıo: Introdução; 1. Princípio do reconhecimento mútuo; 2. Do mandado de detenção europeu; 3. Do controle de proporcionalidade no mandado de detenção europeu; Considerações finais; Referências.

\section{INTRODUÇÃo}

O presente trabalho debruça-se sobre delicada questão tratada pela doutrina e jurisprudência no âmbito do direito penal europeu, qual seja, a da elevada quantidade de mandados de detenção que vêm sendo emitidos e, principalmente, a problemática relacionada com a sua utilização para crimes sem maior gravidade.

As sociedades contemporâneas e seus novos modelos de organização têm como uma de suas características mais marcantes a crescente mobilidade de pessoas e capitais, o que cria condições para o surgimento de uma criminalidade transfronteiriça ${ }^{2}$. Neste sentido, conforme prognóstico de Jesús-María Silva Sanchéz, os fenômenos da globalização e da integração econômica têm como um de seus efeitos a conformação de

2 RODRIGUES, Anabela Miranda. Globalização, crime e ciência penal "européia”. In: RODRIGUES, Anabela Miranda. O direito penal europeu emergente. Coimbra: Coimbra Editora, 2008. p. 364. 
novas modalidades de delitos clássicos, assim como o surgimento de novas formas delitivas, que são, notadamente, organizadas e internacionais ${ }^{3}$.

Uma das consequências do efeito negativo deste processo é a ineficácia dos sistemas penais em lidar com esta crescente e recente criminalidade, sendo necessária, portanto, conforme defende Anabela Miranda Rodrigues, uma libertação da política criminal de suas amarras nacionais, devendo ser pensada e colocada em prática de maneira harmonizada no plano internacional, além da necessidade de um maior impulso à cooperação internacional ${ }^{4}$.

Desta forma, se observa a emergência de um direito criminal europeu ${ }^{5}$ que objetiva a instalação de um espaço comum de liberdade, segurança e justiça, tendo como uma de suas principais vias de consolidação, a ideia do reconhecimento mútuo, baseada na confiança mútua entre os Estados, conforme se desenvolverá no decorrer deste trabalho ${ }^{6}$.

Ocorre que, diante deste cenário, e conforme já havia sido prognosticado por Silva Sánchez, o direito penal da era da globalização tem se

3 O autor define como "globalização econômica" um fenômeno caracterizado pela eliminação das restrições às transações entre Estados e pela ampliação dos mercados. A "integração", por sua vez, é marcada pela busca de um mercado comum entre os países, com livre tráfego de pessoas, serviços, capitais e mercadorias, resultantes da eliminação de barreiras alfandegárias e outros obstáculos à livre circulação. (SILVA SÁNCHEZ, Jesús-María. La expansión del derecho penal: aspectos de la política criminal en las sociedades postindustriales. 3. ed. Madrid: Edisofer S.L., 2011. p. 88-90).

4 RODRIGUES, Anabela Miranda. Globalização, crime e ciência penal "européia”. In: RODRIGUES, Anabela Miranda. O direito penal europeu emergente. Coimbra: Coimbra Editora, 2008. p. 370.

5 Anabela Miranda Rodrigues entende que a denominação "direito penal europeu" é a mais adequada, uma vez que, se por um lado, o termo "europeu" pode ser aplicado não apenas no âmbito da União Europeia, mas também, por exemplo, no do Conselho da Europa, por "direito penal" haveria a restrição ao direito material e processual, excluindo de seu âmbito as questões atinentes à segurança interna da União. (RODRIGUES, Anabela Miranda. $O$ direito penal europeu emergente. Coimbra: Coimbra Editora, 2008. p. 13). Entendemos, porém, que uma vez se tratando de uma temática localizada na intersecção entre o direito penal e o processual penal, a terminologia mais adequada seria "direito criminal europeu".

6 RODRIGUES, Anabela Miranda. Globalização, crime e ciência penal "européia". In: RODRIGUES, Anabela Miranda. O direito penal europeu emergente. Coimbra: Coimbra Editora, 2008. p. 370. 
mostrado não apenas cada vez mais harmonizado, mas também, menos garantista, com relativizações de garantias político criminais, substantivas e processuais penais ${ }^{7}$. Exemplo disto, conforme será demonstrado, é a própria forma pela qual o mandado de detenção europeu vem sendo utilizado, sem a necessária restrição à criminalidade mais grave, nos termos para os quais foi elaborado. É neste sentido, inclusive, que assevera Vervaele ao dizer que este instrumento ainda será, por muito tempo, questionado perante os tribunais constitucionais, a Corte Europeia de Justiça e a Corte Europeia de Direitos Humanos, uma vez que vem sendo baseado, por ora, somente na ideia de confiança, mas não na harmonização das salvaguardas processuais aplicáveis ao caso ${ }^{8}$.

Neste mesmo sentido, identifica Joachim Vogel que ao contrário de outrora, quando Estados-Membros vinham celebrando e aplicando acordos com vistas apenas à facilitação e simplificação de procedimentos de entrega, há recente giro político-criminal, uma vez que a crítica sustenta cada vez mais a necessidade da observância das garantias processuais, especialmente no que se refere à proteção dos direitos dos suspeitos e acusados. Assim, defende o autor um necessário equilíbrio no âmbito da cooperação internacional entre a eficácia do procedimento e os interesses das pessoas afetadas ${ }^{9}$.

Tendo-se em vista, portanto, a necessária ponderação entre os interesses persecutórios e, conforme defende Jürgen Wolter, da proteção de direitos fundamentais do autor em conformidade com o princípio da proporcionalidade ${ }^{10}$, busca-se, com o presente trabalho, analisar a eventual

7 SILVA SÁNCHEZ, Jesús-María. La expansión del derecho penal: aspectos de la política criminal en las sociedades postindustriales. 2. ed. rev. y ampl. Madrid: Civitas, 2001. p. 83-84.

8 VERVAELE, John A. E. European Criminal Justice in the post-Lisbon area security and justice. Quaderni della facoltà di giurisprudenza, n. 5, Trento: Università Degli Studi di Trento, 2014. p. 256.

9 VOGEL, Joachim. Cooperación penal: cinco tendencias. Cinco propuestas para una acción futura. In: ARROYO ZAPATERO, Luis. NIETO MARTIN, Adán. El derecho penal de la Unión Europea: situación actual y perspectivas de futuro. Cuenca. Ediciones de la Universidad de Castilla-La Mancha. 2007. p. 162-163.

10 WOLTER, Jürgen. Derechos humanos y protección de bienes jurídicos en un sistema europeo del derecho penal: In: SILVA SANCHÉZ, Jesús-María et. al. 
admissibilidade de um teste de proporcionalidade a ser realizado pelo Estado de execução, com vistas a garantir a utilização de tal instrumento apenas para a criminalidade mais grave.

Para tanto, mister se faz, inicialmente, uma análise do princípio do reconhecimento mútuo, assim como de sua basilar ideia da confiança entre os Estados-Membros, a fim de averiguar o âmbito no qual se encontra inserido o mandado de detenção europeu, que conforme se observará, é instrumento diretamente decorrente destes preceitos.

\section{Princípio do reconhecimento mútuo.}

No âmbito da União Europeia, observa-se que o conceito tradicional de cooperação é inadequado por existir, na verdade, o que se chama de "sistema europeu de justiça penal integrado"11. Neste sentido, há uma evolução e uma consequente aproximação das legislações entre si, dando origem ao processo conhecido como "harmonização"12. Em face, porém, de certa resistência a este processo em matéria penal, a União estabeleceu como um dos pilares da cooperação a ideia do reconhecimento mútuo, que vem a se concretizar, posteriormente, através do mandado de detenção europeu ${ }^{13}$. Conforme explica André Klip, este princípio significa que uma decisão tomada por uma autoridade judiciária competente para tal em um Estado-Membro, tem que ser reconhecida e executada em outro como se por ele tivesse sido proferida. Inclusive, o autor defende que o

Fundamentos de un sistema europeo del derecho penal. Barcelona. José Maria Bosch Editor, 1995. p. 37.

11 Segundo Joachim Vogel, as principais características deste sistema são: a cooperação entre os Estados-Membros com base no reconhecimento e na confiança mútua; a aproximação e compatibilização entre si dos sistemas de justiça, formando a chamada "harmonização"; e a coordenação das atividades por entidades europeias, tais como a Europol e a Eurojust. VOGEL, Joachim. Cooperación penal: cinco tendencias. Cinco propuestas para una acción futura. In: ARROYO ZAPATERO, Luis. NIETO MARTIN, Adán. El derecho penal de la Unión Europea: situación actual y perspectivas de futuro. Cuenca. Ediciones de la Universidad de Castilla-La Mancha. 2007. p. 158-159.

12 Idem, ibidem.

13 VALENTE, Manuel Monteiro Guedes. Do mandado de detenção europeu. Coimbra: Almedina, 2006. p. 14-15. 
papel do Estado de execução deve ser, em tese, a mera execução, não devendo ser reexaminada qualquer matéria ${ }^{14}$.

Isto se dá, principalmente, em virtude da regência da ideia de um espaço comum de liberdade, segurança e justiça, sendo que esta última tem como consequência necessária, a livre circulação de decisões judiciais. Busca-se com esta medida, alcançar uma maior celeridade e eficiência no processo de cooperação, tendo-se em vista que a inexistência de um controle por parte do Estado de execução tornaria, em tese, o mesmo mais simplificado e possibilitaria o estabelecimento de prazos mais restritos para sua finalização, falando-se, inclusive, em certa automaticidade da execução das decisões ${ }^{15}$.

Sendo fundamental, portanto, para a consagração do espaço europeu de justiça, o princípio do reconhecimento mútuo, no que se refere à matéria penal, que tem sua origem nas Conclusões do Conselho Europeu de Tampere, em 15 e 16 de outubro de $1999^{16}$, a partir de quando passou a ser considerado a pedra de toque da cooperação internacional em matéria penal ${ }^{17}$.

Não era, porém, conforme elucida John Spencer, um instrumento novo, uma vez que, no âmbito civil, já havia sido tratado pela Convenção

14 KLIP, André. European criminal Law. An integrative approach. Oxford: Intersentia, 2009. p. 330-331.

15 RODRIGUES, Anabela Miranda. Judicial cooperation in criminal matters, the principle of proportionality and the effectiveness of the European Arrest Warrant. Cahiers de defense sociale : bulletin de la Societé International de Défense Sociale pour une politique criminelle humaniste, Milano, n. 38, p. 82-90, 2013. p. 83.

16 “33. Um maior reconhecimento mútuo das sentenças e decisões judiciais e a necessária aproximação da legislação facilitariam a cooperação entre as autoridades e a protecção judicial dos direitos individuais. Por conseguinte, o Conselho Europeu subscreve o princípio do reconhecimento mútuo que, na sua opinião, se deve tornar a pedra angular da cooperação judiciária na União, tanto em matéria civil como penal. Este princípio deverá aplicar-se às sentenças e outras decisões das autoridades judiciais." (CONSELHO EUROPEU DE TAMPERE, 15 e 16 DE OUTUBRO DE 1999. Conclusões da presidência. Disponível em: <http://www.europarl.europa.eu/summits/tam_pt.htm>. Acesso em 17 mai. 2017).

17 RODRIGUES, Anabela Miranda. Comentários aos artigos $82^{\circ}$. a $84^{\circ}$. do Tratado de Lisboa. In: PORTO, Manuel Lopes; ANASTÁCIO, Gonçalo. (coord.). Tratado de Lisboa: anotado e comentado. Coimbra: Almedina, 2002. p. 426-440. p. 428. 
de Bruxelas de 1968, da Comunidade Econômica Europeia, garantindo o reconhecimento e execução de decisões de outro país da Comunidade. Até mesmo no sistema penal, o Reino Unido adotava um sistema semelhante, garantindo que as decisões de uma autoridade judiciária de um de seus países membros, sejam reconhecidas automaticamente em outro ${ }^{18}$.

No que se refere à União Europeia, porém, foi entre os anos de 2000 e 2001 que se buscou desenvolver medidas que efetivamente garantissem a execução do referido princípio, tal como foi o caso do Programa Conjunto de 15 de janeiro de $2001^{19}$, dentre as quais se destaca a número 8 , segundo a qual se procura estabelecer, para os crimes mais graves, um regime de entrega baseado no reconhecimento e na execução imediata dos mandados de detenção emitidos por autoridades judiciárias de outros Estados-Membros ${ }^{20}$. Obteve, porém, o referido princípio, consagração expressa, somente com o Tratado de Lisboa, mediante os artigos $67^{\circ}$, n. 3 e $82^{\circ 21}$.

Tal instrumento se baseia, segundo John Spencer, na ideia de que os Estados-Membros comungam de valores comuns, tais como a

18 SPENCER, John. Il principio del mutuo riconoscimento. In: KOSTORIS, Roberto E. (a cura di). Manuale di procedura penale europea. Terza edicione. Milano: Giuffrè Editore, 2017. p. 316-317.

19 UNIÃO EUROPEIA. Programa das medidas destinadas a aplicar o princípio do reconhecimento mútuo. Jornal oficial das Comunidades Europeias. C 12. Ano 44. 15.01.2001.

20 VALENTE, Manuel Monteiro Guedes. Do mandado de detenção europeu. Coimbra: Almedina, 2006. p. 79.

21 “Art.67. [...] 3. A união envida esforços para garantir um elevado nível de segurança, através de medidas de prevenção da criminalidade, do racismo e da xenofobia e de combate contra estes fenômenos, através de medidas de coordenação e de cooperação entre as autoridades policiais e judiciárias e outras autoridades competentes, bem como através do reconhecimento mútuo das decisões judiciais em matéria penal e, se necessário, através da aproximação das legislações penais." "Art. 82. A cooperação judiciária em matéria penal na União assenta-se no princípio do reconhecimento mútuo das sentenças e decisões judiciais e inclui a aproximação das disposições legislativas e regulamentares dos Estados-Membros nos domínios a que se referem o $\mathrm{n}^{\circ} .2$ e o artigo $83^{\circ}$....". (UNIÃO EUROPEIA. Tratado de Lisboa: versão consolidada. Lisboa: Assembleia da República, 2008. Disponível em: <https://www.parlamento.pt/europa/Documents/Tratado_Versao_Consolidada.pdf >. Acesso em 17 mai. 2017). 
democracia e o respeito aos direitos humanos, tendo-se em vista, inclusive, o fato de que todos eles são signatários da Convenção Europeia de Direitos do Homem ${ }^{22}$. Trata-se, porém, do reconhecimento de um standard nacional individual por outro país do bloco europeu e não de um standard discutido de maneira ampla na União Europeia ${ }^{23}$.

Muito importante destacar, porém, que o reconhecimento mútuo, conforme defende Anne Weyembergh, tem como finalidade não apenas o fortalecimento da cooperação entre os Estados-Membros, mas também deve assegurar uma maior garantia de proteção dos direitos fundamentais dos cidadãos ${ }^{24}$. É neste sentido, inclusive, que a ideia do referido princípio se relaciona, também, com a da confiança mútua, uma vez que aquele pressupõe um determinado nível de confiança, do Estado de execução, no ordenamento jurídico do Estado de emissão, no sentido do respeito pelos ideais de liberdade, democracia e respeito pelos direitos do indivíduo.

Podendo ser considerado, portanto, um verdadeiro pressuposto do princípio em comento, a confiança mútua mostra-se também como um conceito base para a cooperação no âmbito da União Europeia. Conforme explica André Klip, o reconhecimento mútuo fora construído sobre a ideia de que as normas e garantias de um Estado-Membro devem estar em certo nível de equivalência com as dos outros, de maneira que a autoridade executora deve poder confiar no fato de que a autoridade requerente está em conformidade com a lei e com os direitos fundamentais ${ }^{25}$.

É assim, pois, que defende Roberto E. Kostoris que o modelo de cooperação baseado no reconhecimento mútuo não pode prescindir de

22 SPENCER, John. Il principio del mutuo riconoscimento. In: KOSTORIS, Roberto E. (a cura di). Manuale di procedura penale europea. Terza edicione. Milano: Giuffrè Editore, 2017. p. 320.

23 MITSILEGAS, Valsamis. EU criminal law. Oxford: Hart Publishing, 2009. p. 118-119.

24 WEYEMBERGH, Anne. European Added Value Assessment: The EU Arrest Warrant: Critical assessment of the existing European arrest warrant framework decision: Annex I. Brussels: European Parlament, 2014. p. 1.

25 KLIP, André. European criminal Law. An integrative approach. Oxford: Intersentia, 2009. p. 331. 
certo nível de harmonização das legislações ${ }^{26}$, uma vez que, nos termos explicados por Anabela Miranda Rodrigues, quanto maior for a aproximação entre os Estados, maior será a confiança entre eles ${ }^{27}$.

Segundo Daniel Flore, este conceito é essencial para a funcionalidade do reconhecimento mútuo, uma vez que este último seria impensável se não houvesse confiança por parte de um Estado de que os sistemas jurídicos e os procedimentos respectivos dos outros Estados-Membros seriam capazes de apresentar um nível minimamente satisfatório de qualidade das decisões, para que possa executá-la de maneira automática ${ }^{28}$.

Para tanto, mister se faz reconhecer a existência de um fundo comum de princípios que fazem parte da União Europeia, ocupando ainda, os direitos fundamentais, posição central neste cenário. Em razão disto, deveria, em tese, poder confiar-se no respeito por parte da autoridade judiciária de emissão destes ditames ${ }^{29}$. Aliás, conforme defende Adán Nieto Martin, baseando-se neste standard homogêneo de proteção de direitos fundamentais, pode se dizer que, ao contrário do reconhecimento mútuo, que faz parte da construção normativa do espaço europeu, a confiança mútua, por sua vez, faria parte de uma constituição sociológica da Europa $^{30}$.

Observa-se, portanto, que na via da construção de um espaço comum de liberdade, segurança e justiça, além da necessária harmonização entre as legislações penais e processuais penais, a cooperação judicial tem

26 KOSTORIS, Roberto E. Diritto europeo e giustizia penale: In: KOSTORIS, Roberto E. (a cura di). Manuale di procedura penale europea. Terza edizione. Milano: Giuffrè Editore, 2017. p. 8.

27 RODRIGUES, Anabela Miranda. O direito penal europeu emergente. Coimbra: Coimbra Editora, 2008. p. 72.

28 FLORE, Daniel. Reconnaissance mutuelle, double incrimination et territorialité. La reconnaissance mutuelle des décisions judiciaires pénales dans l'Union européene, p. 65-77, 2001. p. 75.

29 RODRIGUES, Anabela Miranda. Judicial cooperation in criminal matters, the principle of proportionality and the effectiveness of the European Arrest Warrant. Cahiers de defense sociale : bulletin de la Societé International de Défense Sociale pour une politique criminelle humaniste, Milano, n. 38, p. 82-90, 2013. p. 83.

30 NIETO MARTÍN, Adán. Fundamentos constitucionales del sistema europeo de derecho penal. Direito e Cidadania, v. 7, n. 22, p. 27-89, 2005. p. 30. 
como base as ideias de reconhecimento e confiança mútua entre os Estados e seus respectivos ordenamentos jurídicos, vindo estas, posteriormente, a serem concretizadas através do mandado de detenção europeu.

\section{Do MANDAdo DE DETENÇÃo EUROPEU.}

Conforme exposto, como reflexo do processo de simplificação da cooperação em matéria penal na União Europeia, sendo, ainda, consequência direta do princípio do reconhecimento mútuo, o mandado de detenção europeu mostra-se como primeira concretização deste princípio ${ }^{31}$. Neste sentido, a cooperação em matéria penal deixa de estar sujeita ao duplo controle, qual seja, político e jurídico, passando a ser submetida somente a este último, praticamente abolindo, assim, as tradicionais extradições no âmbito do espaço europeu ${ }^{32}$.

Este instituto pode ser conceituado, de acordo com o art. $1^{\circ}$ da Decisão-Quadro do Conselho da União Europeia, de 13 de junho de 2002, como a decisão de uma autoridade judiciária de um Estado-Membro (autoridade judiciária de emissão) que determina a detenção e a entrega, por outro Estado-Membro (autoridade judiciária de execução), de uma pessoa procurada para efeitos de procedimento penal ou cumprimento de pena ou medida de segurança privativa de liberdade ${ }^{33}$.

31 RODRIGUES, Anabela Miranda. Judicial cooperation in criminal matters, the principle of proportionality and the effectiveness of the European Arrest Warrant. Cahiers de defense sociale : bulletin de la Societé International de Défense Sociale pour une politique criminelle humaniste, Milano, n. 38, p. 82-90, 2013. p. 83.

32 VALENTE, Manuel Monteiro Guedes. Do mandado de detenção europeu. Coimbra: Almedina, 2006. p. 14-15.

33 Neste sentido: "Art. $1^{\circ}$. Definição de mandado de detenção europeu e obrigação de o executar [...] 1. O mandado de detenção europeu é uma decisão judiciária emitida por um Estado-Membro com vista à detenção e entrega por outro Estado-Membro duma pessoa procurada para efeitos de procedimento penal ou de cumprimento de uma pena ou medida de segurança privativas de liberdade." (CONSELHO DA UNIÃO EUROPEIA. 2002/584/JAI: decisão-quadro do Conselho, de 13 de junho de 2002, relativa ao mandado de detenção europeu e aos processos de entrega entre os Estados-Membros. OJ L 190, 18.7.2002. p. 1-20. Disponível em: < http://data.europa.eu/eli/ dec_framw/2002/584/oj > . Acesso em 18 mai. 2017). 
Ele se caracteriza através de quatro elementos fundamentais: (1) formalmente, pode se dizer que o mesmo trata-se de um mandado, ou seja, uma ordem; (2) materialmente, consubstancia-se, na detenção ou privação de liberdade de uma pessoa para que, posteriormente, seja entregue; (3) espacialmente, tem lugar no âmbito da União Europeia; e (4) organicamente, depende de intervenção do juiz ou do tribunal da relação, no caso Português ${ }^{34}$.

Conforme explica Miguel Monteiro Guedes Valente, ele se sustenta sobre quatro pontos arquitetônicos: com relação a sua (1) natureza, podemos dizer que o mesmo possui uma natureza judiciária, ab initio ad findem, uma vez que substitui o moroso procedimento da extradição e entrega, abolindo o controle político e deixando permanecer apenas o judiciário ${ }^{35}$.

No que se refere a sua (2) formalidade, essencial que respeite o expressamente disposto no artigo $8^{\circ}$ da Decisão-Quadro 2002/584/ $\mathrm{JAI}^{36}$. O conteúdo e as fórmulas do instrumento devem funcionar como

34 VALENTE, Manuel Monteiro Guedes. Do mandado de detenção europeu. Coimbra: Almedina, 2006. p. 122.

35 Ibidem, p. 126.

36 “Artigo $8^{\circ}$. Conteúdo e formas do mandado de detenção europeu [...] 1. O mandado de detenção europeu contém as seguintes informações, apresentadas em conformidade com o formulário em anexo: a) Identidade e nacionalidade da pessoa procurada; b) Nome, endereço, número de telefone e de fax, e endereço de correio electrónico da autoridade judiciária de emissão; c) Indicação da existência de uma sentença com força executiva, de um mandado de detenção ou de qualquer outra decisão judicial com a mesma força executiva abrangida pelo âmbito de aplicação dos artigos $1^{\circ}$. e $2^{\circ}$.; d) Natureza e qualificação jurídica da infracção, nomeadamente à luz do artigo $2^{\circ}$.; e) Descrição das circunstâncias em que a infracção foi cometida, incluindo o momento, o lugar e o grau de participação da pessoa procurada na infracção; f) Pena proferida, caso se trate de uma sentença transitada em julgado, ou a medida da pena prevista pela lei do Estado-Membro de emissão para essa infracção; g) Na medida do possível, as outras consequências da infracção. 2. O mandado de detenção europeu deve ser traduzido na língua oficial ou numa das línguas oficiais do Estado-Membro de execução. No momento da aprovação da presente decisão-quadro ou posteriormente, qualquer Estado-Membro pode indicar, mediante declaração depositada junto do Secretariado-Geral do Conselho, que aceita uma tradução numa ou em várias outras línguas oficiais das instituições das Comunidades Europeias." (CONSELHO DA UNIÃO EUROPEIA. 2002/584/JAI: decisão-quadro do Conselho, de 13 de junho de 2002, relativa ao mandado de detenção europeu e aos processos de entrega entre os 
uma forma de garantia da pessoa objeto do mandado, de maneira que sua não observância acarretará vício de forma e possibilidade de sua não execução ${ }^{37}$.

Desta forma, conforme indicado no artigo em comento, o mandado de detenção deve conter a identificação da pessoa objeto do mandado e da autoridade judiciária de emissão, a indicação de uma sentença ou outra decisão judicial com a força executiva abrangida pelos artigos $1^{\circ}$. e $2^{\circ}$. da Decisão-Quadro ora analisada, a natureza e a qualificação jurídica da infração e a descrição das circunstâncias em que foi cometida, a pena proferida, caso se trate de sentença. Além disso, o instrumento deve ser traduzido para o idioma do país de execução ${ }^{38}$.

Caso não seja atendido algum dos requisitos supracitados, conforme leciona Manuel Valente, ocorrerá vício de forma que deve ter como consequência a não execução do mandado até o seu saneamento, que ocorrerá, na maioria das vezes, através de uma nova emissão ${ }^{39}$.

Caso haja persistência do vício e execução do mandado, entende o referido autor que haverá nulidade e consequente direito de resistência

Estados-Membros. OJ L 190, 18.7.2002. p. 1-20. Disponível em: <http://data. europa.eu/eli/dec_framw/2002/584/oj>. Acesso em 18 de maio de 2017).

CAEIRO, Pedro. O procedimento de entrega previsto no Estatuto de Roma e a sua incorporação no direito português. In: MOREIRA, Vital. [et. al.]. $O$ Tribunal Penal Internacional e a ordem jurídica portuguesa. Coimbra: Coimbra Editora, 2004. p. 69-157. p. 81-82.

38 A Corte Europeia dos Direitos do Homem considerou haver violação ao número 3, do artigo $6^{\circ}$ (a), da Convenção Europeia dos Direitos do Homem, em virtude de condenação, por parte do estado italiano, de cidadão Tcheco sem que lhe fosse possibilitado acompanhar os atos processuais em um idioma que compreendesse. (EUROPEAN COURT OF HUMAN RIGHTS. Case of Brozicek v. Italy. Application no. 10964/84. Strasbourg, 19/12/1989. Disponível em: <http://hudoc.echr.coe.int/eng?i=001-57612>. Acesso em 19 de janeiro de 2018). Conforme explica Vitalino Esposito, no caso, o Tribunal debruçouse sobre a impossibilidade do arguido de defender-se de maneira adequada da acusação que contra ele era oferecida. (ESPOSITO, Vitalino. A aplicação prática dos princípios da Convencão Européia dos Direitos do Homem no processo penal italiano. Revista Portuguesa de Ciência Criminal, Coimbra, v. 4, n. 2, p. 217-239., abr./jun. 1994. p. 237).

39 VALENTE, Manuel Monteiro Guedes. Do mandado de detenção europeu. Coimbra: Almedina, 2006. p. 128-129. 
por parte da pessoa objeto do mandado, que caso seja desrespeitado, enseja a possibilidade de requerimento de habeas corpus por detenção ilegal ${ }^{40}{ }^{41}$.

O terceiro ponto a ser destacado é a sua (3) funcionalidade, que pode ser entendida como a busca por uma maior simplificação e celeridade da cooperação internacional. Conforme afirma Manuel Valente, o mandado de detenção europeu praticamente revogou o tradicional processo de extradição no âmbito europeu, uma vez que aquele fracassou frente ao novo cenário de criminalidade transnacional resultante do constante processo de globalização e integração. Segundo o autor, este instrumento enseja uma configuração antagônica, uma vez que, se por um lado, mostra-se muito funcional no que se refere à concreção de um espaço europeu dotado de segurança, por outro, deve ser coerente com a afirmação de direitos e garantias fundamentais do cidadã $0^{42}$.

Por fim, importante destacar ainda, a (4) teleologia do instituto, que pode ser dividida em teleologia imediata e mediata. Conforme expõe, mais uma vez, Manuel Valente, da Decisão-Quadro referente ao mandado de detenção europeu, podemos extrair dois objetivos principais: imediatamente, a detenção e a entrega de uma pessoa suspeita ou

$40 \mathrm{O}$ autor fundamenta seu posicionamento no n. $1^{\circ}$. do art. $258^{\circ}$. do Código de Processo Penal Português, que dispõe: “Art. 258 . Mandados de detenção: 1 - Os mandados de detenção são passados em triplicado e contêm, sob pena de nulidade: a) A data da emissão e a assinatura da autoridade judiciária ou de polícia criminal competentes; b) A identificação da pessoa a deter; e c) A indicação do facto que motivou a detenção e das circunstâncias que legalmente a fundamentam." Ainda: “Art. 220. Habeas corpus em virtude de detenção ilegal: 1 - Os detidos à ordem de qualquer autoridade podem requerer ao juiz de instrução da área onde se encontrarem que ordene a sua imediata apresentação judicial, com algum dos seguintes fundamentos: a) Estar excedido o prazo para entrega ao poder judicial; b) Manter-se a detenção fora dos locais legalmente permitidos; c) Ter sido a detenção efectuada ou ordenada por entidade incompetente; d) Ser a detenção motivada por facto pelo qual a lei a não permite." (PORTUGAL. DL n. ${ }^{\circ} 78 / 87$, de 17 de fevereiro: aprova o Código de Processo Penal. Revoga o Decreto-Lei n. ${ }^{\circ} 16489$, de 15 de fevereiro de 1929. Disponível em: <http://www.pgdlisboa.pt/leis/lei_mostra_articulado.php?ficha=1\&artigo_id=\&nid=199\&pagina=1\&tabela=leis\&nversao=\&so_miolo=>. Acesso em 16 de janeiro de 2018).

41 VALENTE, Manuel Monteiro Guedes. Do mandado de detenção europeu. Coimbra: Almedina, 2006. p. 128-129.

42 Ibidem, p. 133-135. 
condenada, enquanto que, mediatamente, busca-se a submissão da mesma a um procedimento penal ou ao cumprimento de uma condenaçãa ${ }^{43}{ }^{44}$.

Defende, porém, o referido autor, que tendo por base os princípios reitores da construção do espaço comum europeu, a teleologia do mandado de detenção deve ter um maior alcance. Assim, enquanto imediatamente se buscaria a detenção de uma pessoa procurada por ser suspeita ou arguida pela prática de um crime para que, verificados os quesitos formais e materiais e reputada a inexistência de causas de motivos de não execução ou a situação de prestação de garantias, a mesma seja entregue para a autoridade judiciária de emissão, a teleologia mediata, por sua vez, seria promover a ação penal de modo a poder investigar e julgar a pessoa suspeita ou arguida, ou executar a sentença de condenação ${ }^{45}$.

Importante destacar ainda, que a detenção almejada pelo mandado de detenção europeu deve ter caráter precário, temporário e provisório $^{46}$. Com isso queremos dizer que a mesma deve seguir as disposições

43 Dos considerandos da decisão quadro, extrai-se que: "(5) O objectivo que a União fixou de se tornar um espaço de liberdade, de segurança e de justiça conduz à supressão da extradição entre os Estados-Membros e à substituição desta por um sistema de entrega entre autoridades judiciárias. Acresce que a instauração de um novo regime simplificado de entrega de pessoas condenadas ou suspeitas para efeitos de execução de sentenças ou de procedimento penal permite suprimir a complexidade e a eventual morosidade inerentes aos actuais procedimentos de extradição. As relações de cooperação clássicas que até ao momento prevaleceram entre Estados-Membros devem dar lugar a um sistema de livre circulação das decisões judiciais em matéria penal, tanto na fase pré-sentencial como transitadas em julgado, no espaço comum de liberdade, de segurança e de justiça." (CONSELHO DA UNIÃO EUROPEIA. 2002/584/JAI: decisão-quadro do Conselho, de 13 de junho de 2002, relativa ao mandado de detenção europeu e aos processos de entrega entre os Estados-Membros. OJ L 190. 18.7.2002. p. 1-20. Disponível em: <http://data. europa.eu/eli/dec_framw/2002/584/oj>. Acesso em 20 de maio de 2017).

VALENTE, Manuel Monteiro Guedes. Do mandado de detenção europeu. Coimbra: Almedina, 2006. p. 136.

Ibidem, p. 139.

Questão problemática é levantada por Víctor Moreno Catena, no que se refere ao tempo de detenção para a execução da ordem. Segundo o autor, caso se trate de entrega para a execução da pena ou medida de segurança, deve ser informado ao Estado de emissão o tempo de privação de liberdade, para que seja descontada da pena a ser cumprida. Situação mais delicada, porém, mostra-se quando se trata de ordem para o exercício de ações penais que, ao 
previstas nas leis processuais penais e estar sujeita, em qualquer caso, à homologação judicial, sendo que esta autoridade pode, caso entenda cabível, substituí-la por outras medidas de coação ${ }^{47}$.

Tendo-se em vista estes pontos, nomeadamente a funcionalidade do instituto, que não deve se esgotar na busca de maior eficiência e celeridade do procedimento de cooperação, mas sim, também assegurar um espaço comum de garantia dos direitos fundamentais do cidadão; e tendo como base uma orientação funcional-teleológica do processo penal, ou seja, do processo como instrumento de política criminal ${ }^{48}$, temos que o mandado de detenção europeu não pode se exaurir na disposição positiva

final, resultam em absolvição. Para tais casos, defende o autor a possibilidade de indenização ao arguido, solução, porém, que por não estar consagrada em todos os ordenamentos, pode não ser aplicada na prática. (MORENO CATENA, Víctor. La orden europea de detención en España. Revista del Poder Judicial, Madrid, n. 78, p. 11-38., 2005. p. 36)

47 Neste sentido: “defendemos que a privação da liberdade de uma pessoa com um MDE, em Portugal, é cautelar, precária, temporária e provisória, porque, por um lado, a detenção da pessoa procurada segue os trâmites do CPP e, por outro, duas ordens de razão corroboram esta posição: primeiro, porque quem operacionaliza a detenção será, com toda a certeza, um OPC, sob determinação da AJ competente para a promoção de execução - MP junto do tribunal da relação competente - ao qual comunica por escrito a efetivação da detenção; segundo, porque a AJ competente para a promoção da execução do MDE em Portugal - o MP junto do tribunal da relação competente, sendo este o da área de domicílio da pessoa procurada ou da área onde aquela se encontra - deverá, primeiramente, ouvi-la sumária e pessoalmente e logo que seja possível. O MP deve, ainda, informá-la da existência e do conteúdo do MDE, assim como da possibilidade de consentir na sua entrega à AJ de emissão, e promover a audição da pessoa detida, no prazo máximo de quarenta e oito horas após a detenção, pelo juiz relator para que aprecie a validade da mesma e decida da sua manutenção, que, em caso de libertá-la, pode aplicarlhe uma das medidas de coacção estipuladas pelo CPP. A detenção de uma pessoa com base num MDE está, desta feita, "sujeita à condição resolutiva de homologação judicial” [neste ponto, cita, o autor, Maia Gonçalves], pois não é uma solução definitiva e inalterável." (VALENTE, Manuel Monteiro Guedes. Do mandado de detenção europeu. Coimbra: Almedina, 2006. p. 124-126).

48 Conforme explica Fernando Fernandes, na via de construção de um modelo processual penal, há que se conciliar os vetores de garantia do cidadão, com as da eficiência e funcionalidade do sistema punitivo. Assim, deve ser buscada a maior eficiência e funcionalidade possível do processo penal dentro de sua tradicional função de garantia. (FERNANDES, Fernando. O processo penal como instrumento de política criminal. Coimbra: Almedina, 2001. p. 54). 
da Decisão-Quadro do Conselho da União Europeia, de 13 de junho de 2002, mas sim, deve ser estruturado de maneira político-criminalmente orientada, buscando não apenas a concretização de um espaço comum de liberdade segurança e justiça, mas também e principalmente de um espaço comum e democrático de direito ${ }^{49}$.

Ao se processar, portanto, sob a égide do ordenamento do Estado de execução, este deve respeitar as finalidades do processo penal, visando, nomeadamente, a realização da justiça, a descoberta da verdade e o restabelecimento da paz jurídica, mas sem se descuidar, é óbvio, dos direitos e garantias fundamentais, que devem sofrer as menores restrições possíveis durante o procedimento ${ }^{50}$.

O exposto é de suma importância, tendo-se em vista, principalmente, o receio inaugurado com o Conselho de Tampere de 1999, de que a construção do espaço europeu seja excessivamente enfocada no viés repressivo e securitário e deixe desamparadas as garantias individuais ${ }^{51}$. O referido temor, inclusive, pode-se dizer ter sido reforçado em razão do estabelecimento de um reconhecimento mútuo não necessariamente vinculado com um nível suficiente de harmonização penal e processual penal, como deveria de ser ${ }^{52}$.

Tendo-se em vista o exposto, a questão que se coloca é relativa à automaticidade da execução do mandado de detenção europeu, ou, colocada de outra forma: cumpridos os requisitos formais do referido instrumento e não sendo o caso de eventual motivo de não execução

49 VALENTE, Manuel Monteiro Guedes. Do mandado de detenção europeu. Coimbra: Almedina, 2006. p. 138.

50 Neste sentido, conforme explica Maria João Antunes, costuma-se atribuir ao processo penal as finalidades essenciais de realização da justiça, descoberta da verdade, proteção dos direitos fundamentais das pessoas perante o Estado e o restabelecimento da paz jurídica. (ANTUNES, Maria João. Direito processual penal. Coimbra: Almedina, 2016. p. 14).

51 Sobre a importância do Conselho de Tampere como inauguração de uma nova fase no âmbito da União Europeia: RODRIGUES, Anabela Miranda; MOTA, José Luís Lopes da. Para uma política criminal européia: quadro e instrumentos jurídicos da cooperação judiciária em matéria penal no espaço da União Europeia. Coimbra: Coimbra Editora, 2002. p. 90 e ss.

52 VALENTE, Manuel Monteiro Guedes. Do mandado de detenção europeu. Coimbra: Almedina, 2006. p. 71. 
previsto na Decisão-Quadro 2002/584/JAI ${ }^{53}$, o seu cumprimento deve ser

53 "Artigo $3^{\circ}$. Motivos de não execução obrigatória do mandado de detenção europeu: A autoridade judiciária do Estado-Membro de execução (a seguir designada "autoridade judiciária de execução" recusa a execução de um mandado de detenção europeu nos seguintes casos: 1 . Se a infracção na origem do mandado de detenção estiver abrangida por amnistia no Estado-Membro de execução, quando este for competente para o respectivo procedimento penal nos termos da sua legislação penal; 2. Se das informações de que dispõe a autoridade judiciária de execução resultar que a pessoa procurada foi definitivamente julgada pelos mesmos factos por um Estado-Membro, na condição de que, em caso de condenação, a pena tenha sido cumprida ou esteja actualmente em cumprimento ou não possa já ser cumprida segundo as leis do Estado-Membro de condenação; 3. Se, nos termos do direito do Estado-Membro de execução, a pessoa sobre a qual recai o mandado de detenção europeu não puder, devido à sua idade, ser responsabilizada pelos factos que fundamentam o mandado de detenção europeu. Artigo $4^{\circ}$. Motivos de não execução facultativa do mandado de detenção europeu: A autoridade judiciária de execução pode recusar a execução de um mandado de detenção europeu: 1. Se, num dos casos referidos no n.o 4 do artigo 2.o, o facto que determina o mandado de detenção europeu não constituir uma infracção nos termos do direito do Estado-Membro de execução; todavia, em matéria de contribuições e impostos, de alfândegas e de câmbios, a execução do mandado de detenção europeu não pode ser recusada pelo facto de a legislação do Estado-Membro de execução não impor o mesmo tipo de contribuições e impostos ou não prever o mesmo tipo de regulamentação em matéria de contribuições e impostos, de alfândegas e de câmbios que a legislação do EstadoMembro de emissão; 2. Quando contra a pessoa sobre a qual recai o mandado de detenção europeu for movido procedimento penal no Estado-Membro de execução pelo mesmo facto que determina o mandado de detenção europeu; 3. Quando as autoridades judiciárias do Estado-Membro de execução tiverem decidido não instaurar procedimento criminal, ou pôr termo ao procedimento instaurado, pela infracção que determina o mandado de detenção europeu ou quando a pessoa procurada foi definitivamente julgada num Estado-Membro pelos mesmos factos, o que obsta ao ulterior exercício da acção penal; 4 . Quando houver prescrição da acção penal ou da pena nos termos da legislação do Estado-Membro de execução e os factos forem da competência desse Estado-Membro nos termos da sua legislação penal; 5. Se das informações de que dispõe a autoridade judiciária de execução resultar que a pessoa procurada foi definitivamente julgada pelos mesmos factos por um país terceiro, na condição de que, em caso de condenação, a pena tenha sido cumprida ou esteja actualmente em cumprimento ou não possa já ser cumprida segundo as leis do país de condenação; 6. Se o mandado de detenção europeu tiver sido emitido para efeitos de cumprimento de uma pena ou medida de segurança privativas de liberdade, quando a pessoa procurada se encontrar no Estado-Membro de execução, for sua nacional ou sua residente e este Estado se comprometa a executar essa pena ou medida de segurança nos termos do 
automático ou tem a autoridade de execução uma margem para controle? E se positiva a resposta para esta questão, quais seriam seus limites?

\section{Do CONTROLE DE PROPORCIONALIDADE NO MANDADO DE DETENÇÃO EUROPEU.}

Conforme assevera Anabela Miranda Rodrigues, a discussão da maior ou menor automaticidade da execução do mandado de detenção europeu tem recebido especial atenção em razão da emissão de uma grande quantidade de mandados relacionados a crimes considerados menos graves $^{54}$. Ao contrário de seu foco inicial, qual seja, o da facilitação da persecução da criminalidade mais grave, os limites previstos pelo artigo $2^{\circ}$. da Decisão-Quadro do Conselho da União Europeia, de 13 de junho de $2002^{55}$ não permitem garantir a pretendida filtragem. Exemplo disto

seu direito nacional; 7. Sempre que o mandado de detenção europeu disser respeito a infracção que: a) Segundo o direito do Estado-Membro de execução, tenha sido cometida, no todo ou em parte, no seu território ou em local considerado como tal; ou b) Tenha sido praticada fora do território do Estado-Membro de emissão e o direito do Estado-Membro de execução não autorize o procedimento penal por uma infracção idêntica praticada fora do seu território." (CONSELHO DA UNIÃO EUROPEIA. 2002/584/JAI: decisão-quadro do Conselho, de 13 de junho de 2002, relativa ao mandado de detenção europeu e aos processos de entrega entre os Estados-Membros. OJ L 190. 18.7.2002. p. 1-20. Disponível em: <http://data.europa.eu/eli/dec_ framw/2002/584/oj >. Acesso em 20 mai. 2017).

54 Neste sentido, observa-se, a título exemplificativo, a decisão do Tribunal da Relação de Coimbra no sentido da legitimidade de um mandado de detenção europeu para um indivíduo condenado por "falso testemunho" a uma pena de 186 dias: "1. É legal a emissão de mandado de detenção europeu (MDE) contra condenado, cidadão nacional que se encontre no estrangeiro, Espaço Schengen e que tenha de cumprir 186 dias de pena de prisão subsidiária.” (TRIBUNAL DA RELAÇÃO DE COIMBRA. Acórdão 585/05.5TATNV-A.C1. Relator: Calvário Antunes. Data: 05/05/2010. Disponível em: <http://www. dgsi.pt/jtrc.nsf/c3fb530030ea1c61802568d9005cd5bb/3ba4e4b6069be5bc8025772a0035606c? OpenDocument\&Highlight=0, mandado,de,deten\%C3\%A7\%C3\%A3o,europeu>. Acesso em 18 jan. de 2018).

55 “Artigo $2^{\circ}$. Âmbito de aplicação do mandado de detenção europeu: 1 . O mandado de detenção europeu pode ser emitido por factos puníveis, pela lei do Estado-Membro de emissão, com pena ou medida de segurança privativas de liberdade de duração máxima não inferior a 12 meses ou, quando tiver sido 
é o caso do crime de furto, que por ser punível em basicamente todos os Estados-Membros, e se encontrar dentro dos limites estipulados pela normativa supracitada, pode ser a base para a emissão de um mandado de detenção europeu, seja se tratando de um grande furto, seja se tratando de um caso de shoplifiting ${ }^{56}$.

Assim, conforme explica Juan de Miguel Zaragoza, enquanto o número 1 do artigo $2^{\circ}$. estabelece um limite mínimo de 12 (doze) meses

decretada uma pena ou aplicada uma medida de segurança, por sanções de duração não inferior a quatro meses. 2. As infracções a seguir indicadas, caso sejam puníveis no Estado-Membro de emissão com pena ou medida de segurança privativas de liberdade de duração máxima não inferior a três anos e tal como definidas pela legislação do Estado-Membro de emissão, determinam a entrega com base num mandado de detenção europeu, nas condições da presente decisão-quadro e sem controlo da dupla incriminação do facto: - participação numa organização criminosa, - terrorismo, - tráfico de seres humanos, - exploração sexual de crianças e pedopornografia, - tráfico ilícito de estupefacientes e de substâncias psicotrópicas, - tráfico ilícito de armas, munições e explosivos, corrupção, - fraude, incluindo a fraude lesiva dos interesses financeiros das Comunidades Europeias na acepção da convenção de 26 de Julho de 1995, relativa à protecção dos interesses financeiros das Comunidades Europeias, - branqueamento dos produtos do crime, - falsificação de moeda, incluindo a contrafacção do euro, - cibercriminalidade, - crimes contra o ambiente, incluindo o tráfico ilícito de espécies animais ameaçadas e de espécies e essências vegetais ameaçadas, - auxílio à entrada e à permanência irregulares, - homicídio voluntário, ofensas corporais graves, - tráfico ilícito de órgãos e de tecidos humanos, - rapto, sequestro e tomada de reféns, - racismo e xenofobia, - roubo organizado ou à mão armada, - tráfico de bens culturais incluindo antiguidades e obras de arte, - burla, - extorsão de protecção e extorsão, - contrafacção e piratagem de produtos, - falsificação de documentos administrativos e respectivo tráfico, - falsificação de meios de pagamento, - tráfico ilícito de substâncias hormonais e outros factores de crescimento, - tráfico ilícito de materiais nucleares e radioactivos, - tráfico de veículos roubados, - violação, - fogo-posto, - crimes abrangidos pela jurisdição do Tribunal Penal Internacional, - desvio de avião ou navio, - sabotagem." (CONSELHO DA UNIÃO EUROPEIA. 2002/584/JAI: decisão-quadro do Conselho, de 13 de junho de 2002, relativa ao mandado de detenção europeu e aos processos de entrega entre os Estados-Membros. OJ L 190. 18.7.2002. p. 1-20. Disponível em: <http://data.europa.eu/eli/dec_ framw/2002/584/oj>. Acesso em 20 mai. 2017).

56 RODRIGUES, Anabela Miranda. Judicial cooperation in criminal matters, the principle of proportionality and the effectiveness of the European Arrest Warrant. Cahiers de defense sociale : bulletin de la Societé International de Défense Sociale pour une politique criminelle humaniste, Milano, n. 38, p. 82-90, 2013. p. 84-85. 
para pena em abstrato e 4 (quatro) meses para pena em concreto, o número dois contem uma lista de crimes, para os quais exige-se uma pena mínima em abstrato de 03 (três) anos, mas para os quais, é levado em conta somente o Estado de emissão, não importando se a conduta é tipificada no Estado de execução ${ }^{57}$.

A grande questão é que, conforme exposto, os parâmetros previstos pela Decisão-Quadro de 13 de junho de 2002, nomeadamente os dispostos pelo artigo $2^{\circ}$, n. 1 e 2 , não são suficientes para garantir a restrição do mandado de detenção europeu àquela criminalidade para a qual fora concebida, qual seja, a considerada criminalidade grave.

Pelo contrário, os limites mínimos previstos pelo n. 1 do artigo em comento são irrisórios, situação que não é corrigida pelo princípio da dupla incriminação, uma vez há vários exemplos de condutas que são tipificadas por boa parte dos ordenamentos jurídico-penais europeus e encontram-se abrangidos pelo mesmo, não podendo ser considerados, porém, necessariamente como graves ${ }^{58}$.

Além disso, conforme explica Sabine Gless, há um temor de que o reconhecimento mútuo leve a um aumento unilateral de punibilidade, uma vez que, visando um aumento de eficiência à custa dos indivíduos, há um inegável desequilíbrio nas práticas relativas ao mandado de detenção europeu, em razão do limitado poder de ação da defesa no Estado de execução ${ }^{59}$. Aliás, conforme destaca Francisco J. Fonseca Morillo, se comparado com a proposta inicial da Comissão, o texto atual da

57 MIGUEL ZARAGOZA, Juan de. Algunas consideraciones sobre la Decisión Marco relativa a la orden de detención europea y a los procedimientos de entrega en la perspectiva de la extradición. Actualidad Penal, Madrid, v. 1, n. 4, p. 139-158., jan. 2003. p.147-148.

58 Neste sentido, além do já supracitado crime de furto, observam-se outros crimes patrimoniais, tais como o "furto de uso", previsto no Art. $208^{\circ}$. do Código Penal Português, "dano", previsto pelo Art. 212 ., e "receptação", previsto pelo Art. $231^{\circ}$. do mesmo diploma. (PORTUGAL. DL n. ${ }^{\circ} 48 / 95$, de 15 de Março: aprova o Código Penal. Disponível em: <http://www.pgdlisboa.pt/ leis/lei_mostra_articulado.php?ficha $=1 \&$ artigo_id $=\&$ nid $=109$ \&pagina $=1 \&$ tabela=leis\&nversao=\&so_miolo=>. Acesso em 16 jan. 2018).

59 GLESS, Sabine. A Europa vista a partir de uma perspectiva alemã: um desafio para a defesa em processo penal. Revista Portuguesa de Ciência Criminal, Coimbra, v. 21, n. 3, p. 395-426., jul./set. 2011. p. 417. 
Decisão-Quadro 2002/584/JAI restringiu várias disposições destinadas a aumentar o nível de garantias dos arguidos ${ }^{60}$.

Neste mesmo sentido, defende Sarah Haggenmüller que, apesar de as estatísticas coletadas entre os anos de 2005 e 2010 demonstrarem um suposto sucesso do instrumento em comento, uma vez que mais de 68.000 (sessenta e oito mil) mandados foram emitidos, com uma significativa redução do tempo de execução se comparado com o antigo modelo de extradição, um olhar mais atento leva a conclusão de que a utilização do mandado de detenção europeu está ultrapassando os limites para os quais fora concebido, ainda mais por se tratar de medida coercitiva que envolve privação de liberdade ${ }^{61}$.

Assim sendo, o Conselho da União Europeia, em sua reunião de 3 e 4 de julho de 2010, definiu como uma das prioridades o tratamento do problema da desproporcionalidade dos mandados de detenção europeu. Neste sentido, houve consenso relativo à necessidade de um controle de proporcionalidade com o objetivo de evitar a emissão de mandados relacionados a crimes que, muito embora abrangidos pelos limites previstos pelo número 1, do artigo $2^{\circ}$. da Decisão-Quadro de 13 de junho de 2002, não apresentem um determinado nível de gravidade ${ }^{62}{ }^{63}$.

60 Exemplifica, o autor, com a previsão do direito a um advogado a partir do momento da detenção, no texto original, enquanto que o atual faz apenas uma remissão ao ordenamento jurídico do Estado de execução; cita ainda, a previsão, na versão original, de um marco detalhado de possibilidades de colocação em liberdade da pessoa objeto do mandado, enquanto que, na versão atual, remete apenas ao ordenamento interno do Estado de execução; por fim, importante destacar que o antigo artigo 21 previa a colocação em liberdade da pessoa, após o vencimento do prazo da detenção, sem que tenha havido a entrega. (FONSECA MORILLO, Francisco J. La orden de detención y entrega europea. Revista de derecho comunitario europeo, ano 7, n. 14, p. 69-95, 2003. p.79-81).

61 HAGGENMÜLLER, Sarah. The principle of proportionality and the European arrest warrant. Oñati Socio-legal Series [online], v. 3, n. 1, p. 95-106, 2013. p. 98.

62 RODRIGUES, Anabela Miranda. Judicial cooperation in criminal matters, the principle of proportionality and the effectiveness of the European Arrest Warrant. Cahiers de defense sociale : bulletin de la Societé International de Défense Sociale pour une politique criminelle humaniste, Milano, n. 38, p. 82-90, 2013. p. 85.

63 "A confiança na aplicação do mandado de detenção europeu tem sido posta em causa pelo problema recorrente dos mandados de detenção europeus 
Conforme explica Anne Weyembergh, existem três possíveis soluções para o problema em questão. A primeira delas seria elevar os limites previstos pelo artigo $2^{\circ}$. da Decisão-Quadro 2002/584/JAI, opção da qual a autora discorda. Isto porque, segundo ela, eventual elevação destes limiares tornaria os limites mínimos para a emissão de um mandado de detenção superiores aos de um pedido de extradição entre um Estado europeu e um terceiro. Além disto, isso poderia incentivar o aumento das penas em abstrato de determinados crimes em alguns Estados-Membros, a fim de justificar a emissão de mandados de detenção $0^{64}$.

Uma segunda solução seria a adoção de um teste de proporcionalidade no Estado de emissão, sendo possível, inclusive, uma emenda

relativos à entrega de pessoas muitas vezes procuradas por delitos menores. Neste contexto, os debates no Conselho na sequência das conclusões das avaliações dos Estados-Membros[22] revelam que existe um consenso geral entre estes últimos que é necessário um controlo da proporcionalidade para evitar que sejam emitidos mandados de detenção europeus relativos a infracções que, embora abrangidas pelo âmbito de aplicação do artigo $2 .^{\circ}, \mathrm{n} .^{\circ}$ 1 [23], da decisão-quadro do Conselho relativa ao mandado de detenção europeu, não são suficientemente graves para justificar as medidas e a cooperação que a execução de um mandado de detenção europeu exige. Vários aspectos deviam ser considerados antes de emitir um MDE, nomeadamente a gravidade da infracção, a duração da pena, a existência de uma abordagem alternativa menos onerosa tanto para a pessoa procurada como para a autoridade de execução, bem como uma análise custo/benefício da execução do MDE. Quando são emitidos mandados de detenção europeus nos casos em que uma medida de detenção (preventiva) seria normalmente inadequada, produz-se um efeito desproporcionado sobre a liberdade das pessoas procuradas. Além disso, um número excessivo desses pedidos pode ser dispendioso para os Estados-Membros de execução. Pode igualmente conduzir a uma situação em que as autoridades judiciárias de execução (contrariamente às autoridades emissoras) se sentem inclinadas a aplicar um critério de proporcionalidade, introduzindo assim um motivo de recusa que não é conforme com a decisãoquadro do Conselho ou com o princípio do reconhecimento mútuo em que a medida se baseia.". (COMISSÃO EUROPEIA. Relatório da comissão ao parlamento europeu e ao conselho sobre a aplicação desde 2007 da Decisão-Quadro do Conselho, de 13 de junho de 2002, relativa ao mandado de detenção europeu e aos processos de entrega entre os Estados Membros. Bruxelas, 11.02.2011. Disponível em: <http://eur-lex.europa.eu/legal-content/PT/TXT/HTML/?uri=CELEX:52011DC0175\&from=PT>. Acesso em 20 mai. 2017).

64 WEYEMBERGH, Anne. European Added Value Assessment: The EU Arrest Warrant: Critical assessment of the existing European arrest warrant framework decision: Annex I. Brussels: European Parlament, 2014. p. 34-35. 
ao artigo $2^{\circ}$. da Decisão-Quadro em comento, no sentido de que um mandado de detenção não seria emitido quando a extradição da pessoa não fosse necessária e proporcional ${ }^{65}$.

Questão importante, porém, diz respeito ao conteúdo deste controle, ou seja, em que consistiria o teste de proporcionalidade a ser realizado pelo Estado de emissão. Conforme explica Virgílio Afonso da Silva, a proporcionalidade é uma regra de interpretação, utilizada nos casos em que a promoção de um direito fundamental ou interesse coletivo por parte de um ato estatal, implica a restrição de outros direitos fundamentais. Visa, portanto, impedir que a restrição de um direito fundamental se torne desproporcional ${ }^{66}$.

Sua análise se divide em três sub-regras, quais sejam, a da adequação, da necessidade e da proporcionalidade em sentido estrito. Segundo a primeira, tem-se que um meio deve ser considerado adequado quando for apto para fomentar o resultado pretendido ${ }^{67}$, ou seja, deve contribuir para a promoção gradual do fim ${ }^{68}$.

Por sua vez, um meio deve ser considerado necessário quando não haja a possibilidade de realização do fim pretendido através de outro ato que limite de maneira menos intensa o direito fundamental atingido ${ }^{69}$. A análise nesta etapa, conforme leciona Humberto Ávila, deve ser feita em dois momentos, quais sejam, o exame da igualdade de adequação dos meios, verificando se a eventual promoção dos fins através de meios alternativos é equivalente, e o exame do meio menos restritivo, que visa averiguar a eventual menor restrição de direitos fundamentais por aqueles ${ }^{70}$.

Por fim o exame da proporcionalidade em sentido estrito consiste em um sopesamento entre a intensidade da restrição do direito

65 Ibidem, p. 35.

66 SILVA, Virgílio Afonso da. O proporcional e o razoável. Revista dos Tribunais, v. 91, n. 798, p. 23-50, abr. 2002. p. 24.

67 Ibidem, p. 36-37.

68 ÁVILA, Humberto. Teoria dos princípios: da definição à aplicação dos princípios jurídicos. 4.ed.rev. São Paulo: Malheiros, 2005. p. 116.

69 SILVA, Virgílio Afonso da. O proporcional e o razoável. Revista dos Tribunais, v. 91, n. 798, p. 23-50, abr. 2002. p. 38.

70 ÁVILA, Humberto. Teoria dos princípios: da definição à aplicação dos princípios jurídicos. 4.ed.rev. São Paulo: Malheiros, 2005. p. 122. 
fundamental e da importância da realização do direito fundamental ou interesse coletivo que a medida busca promover ${ }^{71}$. Assim, deve ser questionado se as vantagens causadas pela promoção do fim são proporcionais às desvantagens causadas pelos meios utilizados ${ }^{72}$.

Desta forma, no que se refere ao mandado de detenção europeu, deve ser analisado se a sua emissão, primeiramente, é adequada para a fomentação de seus fins, quais sejam, a detenção e a entrega da pessoa objeto do mandado para que seja submetida a um processo penal ou cumpra uma condenação, conforme o caso. Ainda, deve ser ponderado se estes fins não podem ser atingidos de maneira menos gravosa para os direitos fundamentais do indivíduo.

Por fim, deve ser feito um sopesamento entre os interesses persecutórios do Estado de emissão, levando em conta a gravidade do delito e a finalidade imediata da ordem, que pode ser, por exemplo, desde o cumprimento de uma sentença condenatória, até o simples comparecimento para um ato, e as inegáveis restrições de liberdade que são inerentes à detenção e à entrega, questionando se a medida é realmente proporcional $^{73}$. Neste sentido, já decidiu o Tribunal da Relação de Coim-

71 SILVA, Virgílio Afonso da. O proporcional e o razoável. Revista dos Tribunais, v. 91, n. 798, p. 23-50, abr. 2002. p. 40.

72 ÁVILA, Humberto. Teoria dos princípios: da definição à aplicação dos princípios jurídicos. 4.ed.rev. São Paulo: Malheiros, 2005. p. 124.

73 Anabela Miranda Rodrigues entende que devem ser levados em conta também, os custos econômicos para o Estado de execução, que devem fazer parte da ponderação entre os interesses do Estado de emissão e os sacrifícios de liberdade do indivíduo (RODRIGUES, Anabela Miranda. Judicial cooperation in criminal matters, the principle of proportionality and the effectiveness of the European Arrest Warrant. Cahiers de defense sociale : bulletin de la Societé International de Défense Sociale pour une politique criminelle humaniste, Milano, n. 38, p. 82-90, 2013. p. 88). Muito embora, tendamos a concordar com a autora no que se refere à necessidade de consideração dos custos econômicos no momento da emissão do mandado, entendemos que tal ponderação não pode ser realizada através da regra da proporcionalidade, uma vez que ensejaria uma distorção do instituto, uma vez que este fora concebido como forma de impedimento de restrição desproporcional de direitos fundamentais, e não de ponderação entre interesses de Estados. Mister se faz, portanto, uma análise de que forma a disparidade entre os custos econômicos da detenção e entrega de um indivíduo e a importância da mesma para o Estado de emissão pode obstar a emissão ou até mesmo a execução de uma ordem, análise porém, que ultrapassa os limites temáticos do presente trabalho. 
bra, em Acórdão de 21/11/2007, segundo o qual, sendo o mandado de detenção europeu um instrumento de restrição de direito fundamental, ainda mais se considerado seu eventual e possível tempo de duração, deve ser regido não apenas na prossecução, mas também na emissão, pelos princípios da legalidade, da excepcionalidade, da subsidiariedade e da proporcionalidade lato sensu ${ }^{74}$.

Importante destacar, porém, que a emenda do artigo $2^{\circ}$. nos parece desnecessária, uma vez que, conforme destaca Anne Weyembergh, o princípio da proporcionalidade já é consagrado no âmbito europeu, sendo, ainda, tutelado pelas Constituições dos diversos Estados-Membros. Desta forma, independentemente de sua consagração expressa na Decisão-Quadro, deve ser adotado e aplicado o teste de proporcionalidade no Estado de emissão ${ }^{75}$.

A questão que se levanta, porém, é relativa à possibilidade de um controle de proporcionalidade não apenas no âmbito do Estado de emissão, mas também no de execução, configurando, portanto, um duplo teste, sendo esta a terceira possível solução elencada por Anne Weyembergh. Segundo a autora, tal possibilidade ensejaria a recusa da execução, por parte do Estado requerido, de mandados que se mostrem desproporcionais.

74 "1. Traduzindo-se a execução de um mandado de detenção europeu numa restrição importante de um direito fundamental como o direito à liberdade, num horizonte territorial alargado, tendo em conta, igualmente, o período de tempo em que a detenção potencialmente se pode manter sem que seja tomada a decisão final de entrega, conclui-se que não só a sua prossecução, mas também a decisão que a montante é tomada quanto à sua emissão, deverão obedecer aos princípios da legalidade, da excepcionalidade, da subsidiariedade e da proporcionalidade lato sensu. 2. No caso de emissão de mandado de detenção europeu, com fundamento na declaração de contumácia, tendo em consideração as restrições à liberdade que implica, que se projectam para além do território nacional e podem determinar, até à decisão final de entrega, um período de detenção alargado é indispensável proceder à concreta ponderação dos apontados critérios." (TRIBUNAL DA RELAÇÃO DE COIMBRA. Acórdão 210/00.0TBTNV-A.C1. Relator: Jorge Gonçalves. Data: 21/11/2007. Disponível em: <http://www.dgsi.pt/jtrc.nsf/c3fb530030ea1c61802568d9005cd5b$\mathrm{b} / 2 \mathrm{efa} 04 \mathrm{e} 7488 \mathrm{c} 8 \mathrm{~d} 62802573 \mathrm{a} 700628 \mathrm{f} 3 \mathrm{~b}$ ? OpenDocument\&Highlight $=0$, mandado,de,deten\%C3\%A7\%C3\%A3o,europeu>. Acesso em 27 mai. 2017).

WEYEMBERGH, Anne. European Added Value Assessment: The EU Arrest Warrant: Critical assessment of the existing European arrest warrant framework decision: Annex I. Brussels: European Parlament, 2014. p. 35. 
Isto possibilitaria a consideração de elementos que dificilmente seriam levados em conta pelo Estado de emissão, tais como circunstâncias familiares, ou condições de saúde da pessoa objeto do mandado ${ }^{76}$.

Sobre este ponto, já se manifestou o Conselho da União Europeia, entendendo, porém, que tal controle é admissível apenas no âmbito do Estado de emissão. Assim, defendeu-se que qualquer entendimento contrário configuraria tentativa de negativa de execução do mandado com base em motivos não elencados na Decisão-Quadro e em sentido contrário à própria ideia de reconhecimento mútuo ${ }^{77}$.

Com entendimento semelhante, Daniel Flore defende que uma decisão tomada por uma autoridade competente, no Estado-Membro de emissão, em conformidade com as regras deste Estado, não deve ser objeto de controle por parte da autoridade do Estado de execução. Para o autor, em face dos princípios do reconhecimento e da confiança mútua, submeter esta decisão a uma espécie de validação no Estado de execução daria ao instituto uma natureza que não é a qual lhe fora pensada ${ }^{78}$.

Ainda, Anne Weyembergh também entende pela recusa desta solução, tendo como base, primeiramente, a própria filosofia do mandado de detenção europeu, que restaria prejudicada em caso de necessidade de um duplo controle. Além disso, para a autora, este teste de proporcionalidade pressupõe certo nível de conhecimento do sistema de justiça do Estado de emissão, o que tornaria a implementação prática desta proposta bastante dificultosa ${ }^{79}$.

76 Ibidem, p. 37.

77 RODRIGUES, Anabela Miranda. Judicial cooperation in criminal matters, the principle of proportionality and the effectiveness of the European Arrest Warrant. Cahiers de defense sociale : bulletin de la Societé International de Défense Sociale pour une politique criminelle humaniste, Milano, n. 38, p. 82-90, 2013. p. 87.

FLORE, Daniel. Reconnaissance mutuelle, double incrimination et territorialité. La reconnaissance mutuelle des décisions judiciaires pénales dans l'Union européene, p. 65-77, 2001. p. 76.

79 WEYEMBERGH, Anne. European Added Value Assessment: The EU Arrest Warrant: Critical assessment of the existing European arrest warrant framework decision: Annex I. Brussels: European Parlament, 2014. p. 37. 
O Tribunal da Relação de Lisboa também já se manifestou a respeito, entendendo não ser devida a realização de juízo de proporcionalidade pelo Estado de execução, mas tão somente pelo de emissão ${ }^{80}$.

Não obstante estes fortes argumentos em contrário, entendemos que se faz importante e necessário um juízo de proporcionalidade também no Estado de execução, tendo-se em vista que, no caso concreto, neste tem-se a possibilidade de analisar eventuais circunstâncias que, pelas mais diversas razões, podem não ter sido consideradas pelo Estado de emissão e que podem tornar as restrições de direitos fundamentais do indivíduo mais intensas em caso de sua detenção e entrega, e, consequentemente, desproporcionais em relação às finalidades do Estado de emissão.

Conforme defende Manuel Valente, a total jurisdicionalização do procedimento do mandado de detenção europeu representou, no sentido da proteção dos direitos da pessoa objeto do mandado, um avanço, uma vez que o submete também às garantias processuais do Estado de execução, eliminando, ainda, o juízo político sobre a cooperação. Esta medida se mostra, ainda, como uma concretização do princípio da confiança mútua, uma vez que permite à autoridade de execução exercer não apenas um controle genérico, qual seja, o de saber se um fato gerador preenche ou não uma das infrações da lista ou se é incriminado

80 "I,- A decisão de emissão de um mandado de detenção europeu deverá obedecer ao princípio da proporcionalidade lato sensu, mas o juízo sobre a proporcionalidade compete à autoridade judiciária do Estado de emissão, não cabendo à autoridade judiciária do Estado de execução efectuar qualquer juízo de proporcionalidade sobre a decisão da autoridade judiciária do Estado de emissão de proceder criminalmente contra a pessoa procurada e de ordenar a sua detenção. II.-O princípio da confiança mútua impõe, no que respeita ao espaço de liberdade, segurança e justiça, que cada um dos Estados Membros considere, salvo em circunstâncias excepcionais, que todos os outros Estados Membros respeitam o direito da União e, muito em especial, os direitos fundamentais reconhecidos por este direito." (TRIBUNAL DA RELAÇÃO DE LISBOA. Acórdão 546/17.1YRLSB5. Relator: Jorge Gonçalves. Data: 07/04/2017. Disponível em: <http://www.dgsi.pt/jtrl. nsf/33182fc732316039802565fa00497eec/96960c7c05dc8e108025813 300466ba7? OpenDocument\&Highlight $=0$, mandado, de, deten\%C3\%A7\%C3\%A3o,europeu>. Acesso em 18 jan. 2017). 
no Estado de emissão, como também um controle adequado, nos termos do considerando 8 da Decisão-Quadro ${ }^{81 \_82}$.

Tratando-se especificamente do caso português, estando as medidas de coação submetidas ao Código de Processo Penal, deve se obedecer aos princípios balizadores da detenção de qualquer pessoa, ou seja, ser adequada e proporcional ao fim do mandado de detenção europeu, qual seja, a entrega da pessoa detida à autoridade judiciária de emissão, como ainda resultado da inadequação e insuficiência de outras medidas de coação para garantir a execução destas finalidades ${ }^{83}$.

Desta forma, não pode a decisão emitida por uma autoridade judiciária de um Estado-Membro ser automaticamente executada pela autoridade de outro, sem que antes seja realizado um teste de proporcionalidade a fim de averiguar se a detenção e posterior e eventual entrega da pessoa objeto do mandado é adequada, necessária e proporcional em sentido estrito ao interesse persecutório do Estado de emissão ${ }^{84}$.

81 “(8) As decisões sobre a execução do mandado de detenção europeu devem ser objecto de um controle adequado, o que implica que deva ser a autoridade judiciária do Estado-Membro onde a pessoa procurada foi detida a tomar a decisão sobre sua entrega." (CONSELHO DA UNIÃO EUROPEIA. 2002/584/ JAI: decisão-quadro do Conselho, de 13 de junho de 2002, relativa ao mandado de detenção europeu e aos processos de entrega entre os Estados-Membros. OJ L 190. 18.7.2002. p. 1-20. Disponível em: < http://data.europa.eu/ eli/dec_framw/2002/584/oj >. Acesso em 20 de maio de 2017).

VALENTE, Manuel Monteiro Guedes. Do mandado de detenção europeu. Coimbra: Almedina, 2006. p. 170-172.

Ibidem, p. 175.

${ }^{84}$ Conforme explica Cézar Roberto Bitencourt, o princípio da proporcionalidade é consagrado não apenas como critério de interpretação, mas sim, como verdadeira garantia legitimadora e limitadora do poder estatal e de todo o ordenamento jurídico infraconstitucional. Assim, nos termos expostos por Paulo Bonavides, todos os atos estatais passam a ter uma finalidade política ditada por valore éticos extraídos da Constituição [adequação teleológica]; os meios adotados para o alcance de determinada finalidade não podem ultrapassar os limites indispensáveis e menos lesivos possíveis [necessidade]; e todo representante do estado está obrigado a fazer uso apenas de meios adequados e abster-se de meios desproporcionais [proporcionalidade stricto sensu] (BONAVIDES apud BITENCOURT, Cézar Roberto. Tratado de direito penal, volume 1: parte geral. 13. ed. atual. São Paulo: Saraiva, 2008. p. 24-25). 
Neste sentido, o tribunal de apelação de Stuttgart, em decisão de 25 de fevereiro de 2010, entendeu ser admissível um controle de proporcionalidade no Estado de execução, tendo como base os prejuízos à liberdade da pessoa objeto do mandado, assim como seus direitos fundamentais, devendo, porém, em caso de recusa à detenção, o Estado oferecer garantias de que impeçam a fuga do agente e venha a frustrar a eventual posterior entrega ${ }^{85}$.

Conforme consta do acórdão, o princípio da proporcionalidade é uma das tradições constitucionais dos ordenamentos jurídicos dos Estados-Membros, estando, inclusive, previsto pelo artigo $49^{\circ}$., parágrafo $3^{\circ}$., da Carta dos Direitos Fundamentais da União Europeia ${ }^{86}$, se relacionado a um padrão de Direitos Fundamentais reconhecidos no espaço europeu, devendo, portanto, serem aplicados ${ }^{87}$.

Assim, antes de ser executado um mandado de detenção europeu, deve ser realizado um teste de proporcionalidade, tendo este por base, no mínimo, o direito à liberdade da pessoa procurada, as importâncias das

85 OLG STUTTGART. Beschl. v. 25.2.2010 - 1 Ausl. (24) 1246/09, BeckRS 2010, 6922.

86 "Artigo $49^{\circ}$. Princípios da legalidade e da proporcionalidade dos delitos e das penas: 1. Ninguém pode ser condenado por uma acção ou por uma omissão que no momento da sua prática não constituía infracção perante o direito nacional ou o direito internacional. Do mesmo modo, não pode ser imposta uma pena mais grave do que a aplicável no momento em que a infracção foi praticada. Se, posteriormente à infracção, a lei previr uma pena mais leve, deve ser essa a pena aplicada. 2 . O presente artigo não prejudica a sentença ou a pena a que tenha sido condenada uma pessoa por uma acção ou por uma omissão que no momento da sua prática constituía crime segundo os princípios gerais reconhecidos por todas as nações. 3. As penas não devem ser desproporcionadas em relação à infracção.” (PARLAMENTO EUROPEU. Carta dos direitos fundamentais da União Europeia. Jornal Oficial das Comunidades Europeias. C 364/01, 18.12.2000. Disponível em: <http://www.europarl.europa.eu/charter/pdf/text_pt.pdf >. Acesso em 25 mai. 2017).

87 Do original: “Der Grundsatz der Verhältnismäßigkeit im Zusammenhang mit Straftaten und Strafen gehört zu den gemeinsamen Verfassungüberlieferungen der Mitgliedstaaten der Europäischen Union und ist ein allgemeiner Rechtsgrundsatz des Unionrechts. In diesem Sinne bestimmt auch Art. 49 Abs. 3 Charta der Grundrechte der Europäischen Union (ABI. EU Nr. C 303 v. 14.12.2007 S. 1 - GRCh), dass das Strafmaß zur Straftat nicht umverhaltnismäßig sein darf;...” (OLG STUTTGART. Beschl. v. 25.2.2010 - 1 Ausl. (24) 1246/09, BeckRS 2010, 6922). 
subsequentes ações objetivadas pelo Estado requerente com a emissão do mandado e as consequencias legais previstas. Assim, o instrumento pode ser desproporcional quando a pena prevista para o crime em questão seja muito baixa, ou quando a acusação não seja de demasiada importância, não justificando a execução de um mandado de detenção europeu ${ }^{88}$.

Nesta linha, ainda que diante do dever de cooperação em matéria penal baseado no conceito do reconhecimento mútuo, deve haver uma análise exegética das normas perante os princípios da proporcionalidade e da excepcionalidade da entrega da pessoa, sob pena de violação indireta de valores superiores inscritos nomeadamente na Carta Europeia dos Direitos do Homem ${ }^{89}$ e na Carta dos Direitos Fundamentais da União Europeia,

88 Do original: “Bei der rahmen der Verhältnismäßigkeitsprüfung erforderlichen Einzeifallabwägung sind jedenfalls in Rechnung zu stellen das Freiheitsgrundrecht des Verrfolgten, der mit Auslieferungshalt und Durchführung eines Auslieferungsverfahrens verbundene Aufwand, die Bedetung der zugrundeliegenden Tat und die zu erwartende Rechtsfolg. [...] Auslieferungshaft kann insbesondere dann unverhältnismäßig sein, wenn der Tatvorwurf geringe Bedeutung hat und sie Straferwartung nicht im Verhältnis zur Belastung des Verfolgten durch Inhaftnahme und Auslieferung sowie zum Verfahrensaufwand steht." (OLG STUTTGART. Beschl. v. 25.2.2010 - 1 Ausl. (24) 1246/09, BeckRS 2010, 6922).

"Art. $6^{\circ}$. Direito a um processo equitativo. 1. Qualquer pessoa tem direito a que a sua causa seja examinada, equitativa e publicamente, num prazo razoável por um tribunal independente e imparcial, estabelecido pela lei, o qual decidirá, quer sobre a determinação dos seus direitos e obrigações de carácter civil, quer sobre o fundamento de qualquer acusação em matéria penal dirigida contra ela. O julgamento deve ser público, mas o acesso à sala de audiências pode ser proibido à imprensa ou ao público durante a totalidade ou parte do processo, quando a bem da moralidade, da ordem pública ou da segurança nacional numa sociedade democrática, quando os interesses de menores ou a protecção da vida privada das partes no processo o exigirem, ou, na medida julgada estritamente necessária pelo tribunal, quando, em circunstâncias especiais, a publicidade pudesse ser prejudicial para os interesses da justiça. 2 . Qualquer pessoa acusada de uma infracção presume-se inocente enquanto a sua culpabilidade não tiver sido legalmente provada. 3. O acusado tem, como mínimo, os seguintes direitos: a) Ser informado no mais curto prazo, em língua que entenda e de forma minuciosa, da natureza e da causa da acusação contra ele formulada; b) Dispor do tempo e dos meios necessários para a preparação da sua defesa; c) Defender-se a si próprio ou ter a assistência de um defensor da sua escolha e, se não tiver meios para remunerar um defensor, poder ser assistido gratuitamente por um defensor oficioso, quando os interesses da justiça o exigirem; d) Interrogar ou fazer interrogar as testemunhas de acusação e obter a convocação e o interrogatório das testemunhas de defesa nas 
em razão da violação de excesso ${ }^{90}{ }^{91}$. Desta forma, deve o mandado de detenção europeu ser pautado pelo princípio da proporcionalidade, de maneira que a restrição da liberdade da pessoa deve ser proporcional à gravidade da conduta do agente e aos fins de sua entrega, não devendo haver, ainda, outros meios menos onerosos que atinjam estas finalidades ${ }^{92}$.

Tal aplicação, nos termos expostos, é essencial para a consagração de um espaço europeu voltado cada vez mais, não apenas para a segurança, mas também para a proteção dos direitos fundamentais de seus cidadãos, auxiliando na consagração não de um espaço de Estados soberanos, mas sim, do que Anabela Miranda Rodrigues intitula de um espaço de partilha de soberanias ${ }^{93}$.

\section{Considerações finaIS}

Pelo exposto, restou comprovado que embora sejam muito importantes para o modelo de cooperação em matéria penal atualmente adotado no espaço europeu, podendo entendê-los, inclusive, como cruciais

mesmas condições que as testemunhas de acusação; e) Fazer-se assistir gratuitamente por intérprete, se não compreender ou não falar a língua usada no processo". (TRIBUNAL EUROPEU DOS DIREITOS DO HOMEM; COUNCIL OF EUROPE. Convenção europeia dos direitos do homem: com as modificações introduzidas pelos Protocolos n. 11 e 14, acompanhada do Protocolo adicional e dos Protocolos n. 4, 6, 7, 12 e 13. Disponível em: <http://www.echr.coe.int/ Documents/Convention_POR.pdf>. Acesso em 28 mai. 2017).

90 VALENTE, Manuel Monteiro Guedes. Do mandado de detenção europeu. Coimbra: Almedina, 2006. p. 330-331.

91 Importante destacar que, segundo Helmut Satzger, os direitos previstos pelos artigos $47^{\circ}$. a $50^{\circ}$. da Carta dos Direitos Fundamentais da União Europeia, e pelo art. $6^{\circ}$. da Convenção europeia dos direitos do homem, somente estabelecem um standard mínimo de proteção legal, devendo a presente lacuna ter sido preenchida pela Decisão-Quadro, o que não foi feito. (SATZGER, Helmut. International and european criminal law. Oxford: Hart Publishing, 2012. p. 129).

92 VALENTE, Manuel Monteiro Guedes. Do mandado de detenção europeu. Coimbra: Almedina, 2006. p. 334.

93 RODRIGUES, Anabela Miranda. Judicial cooperation in criminal matters, the principle of proportionality and the effectiveness of the European Arrest Warrant. Cahiers de defense sociale : bulletin de la Societé International de Défense Sociale pour une politique criminelle humaniste, Milano, n. 38, p. 82-90, 2013. p. 89-90. 
para o seu funcionamento, o instituto do reconhecimento mútuo e, especialmente, sua posterior concretização através do mandado de detenção europeu, são instrumentos que devem ser utilizados com muita cautela, uma vez que ensejam necessária restrição de direitos fundamentais da pessoa objeto do mandado.

Desta forma, observa-se que a maneira como estes têm sido emitidos em casos nos quais a conduta típica em questão, muito embora dentro dos limites previstos pela Decisão-Quadro do Conselho da União Europeia, de 13 de Junho de 2002, não pode ser considerada suficientemente grave, reforça as dúvidas e temores relativos ao eventual enfoque no viés repressivo na construção do espaço comum europeu de liberdade, segurança e justiça em detrimento, porém, da proteção das garantias dos cidadãos.

No entanto, não entendemos ser necessária e nem mesmo adequada uma elevação dos limiares mínimos do Art. $2^{\circ}$ da Decisão-Quadro do Mandado de Detenção Europeu. Pelo contrário, mister se faz a realização de um teste de proporcionalidade que leve em conta a necessidade, a idoneidade e a proporcionalidade da detenção e entrega da pessoa objeto do mandado, tendo como base os interesses persecutórios do Estado de emissão, em face dos direitos e garantias do indivíduo.

Muito embora seja importante a realização deste juízo no âmbito do Estado requerente, podendo se dizer, inclusive, não haver significativas controvérsias sobre esta possibilidade e até mesmo imperiosidade, entendemos que esta não é suficiente, devendo ser este realizado também no âmbito do Estado requerido, uma vez que nele poderão ser levadas em conta circunstâncias específicas do caso que dificilmente estariam ao alcance das autoridades do Estado de emissão.

Desta forma, não podem os mandados de detenção europeu ser de execução automática quando não abrangidos pelas causas de não-execução, devendo, portanto, serem analisados pela autoridade responsável no Estado de execução, a fim de averiguar sua proporcionalidade para com os fins com ele buscados. Esta é uma importante medida para assegurar o respeito aos limites impostos pela própria teleologia do instituto, tendose em vista as finalidades para as quais fora concebido, ajudando, ainda, a reforçar a ideia de um espaço comum, não de exclusiva repressão, mas também de reforço de garantias e direitos fundamentais. 


\section{REFERÊNCIAS}

ANTUNES, Maria João. Direito processual penal. Coimbra: Almedina, 2016.

ÁVILA, Humberto. Teoria dos princípios: da definição à aplicação dos princípios jurídicos. 4.ed.rev. São Paulo: Malheiros, 2005.

BITENCOURT, Cézar Roberto. Tratado de direito penal, volume 1: parte geral. 13. ed. atual. São Paulo: Saraiva, 2008.

CAEIRO, Pedro. O procedimento de entrega previsto no Estatuto de Roma e a sua incorporação no direito português. In: MOREIRA, Vital. [et. al.]. O Tribunal Penal Internacional e a ordem jurídica portuguesa. Coimbra: Coimbra Editora, 2004. p. 69-157.

COMISSÃO EUROPEIA. Relatório da comissão ao parlamento europeu e ao conselho sobre a aplicação desde 2007da Decisão-Quadro do Conselho, de 13 de junho de 2002, relativa ao mandado de detenção europeu e aos processos de entrega entre os Estados Membros. Bruxelas, 11.02.2011. Disponível em: <http://eur-lex.europa.eu/ legal-content/PT/TXT/HTML/?uri=CELEX:52011DC0175\&from=PT>. Acesso em 20 mai. 2017.

CONSELHO DA UNIÃO EUROPEIA. 2002/584/JAI: decisão-quadro do Conselho, de 13 de junho de 2002, relativa ao mandado de detenção europeu e aos processos de entrega entre os Estados-Membros. OJ L 190, 18.7.2002, p. 1-20. Disponível em: <http://data.europa.eu/eli/dec_framw/2002/584/oj>. Acesso em 18 mai. 2017.

ESPOSITO, Vitalino. A aplicação prática dos princípios da Convencão Européia dos Direitos do Homem no processo penal italiano. Revista Portuguesa de Ciência Criminal, Coimbra, v. 4, n. 2, p. 217-239., abr./jun. 1994.

EUROPEAN COURT OF HUMAN RIGHTS. Case of Brozicek v. Italy. Application no. 10964/84. Strasbourg, 19/12/1989. Disponível em: <http://hudoc.echr.coe. int/eng?i=001-57612>. Acesso em 19 jan. 2018.

FERNANDES, Fernando. O processo penal como instrumento de política criminal. Coimbra: Almedina, 2001.

FONSECA MORILLO, Francisco J. La orden de detención y entrega europea. Revista de derecho comunitario europeo, ano 7, n. 14, p. 69-95, 2003.

FLORE, Daniel. Reconnaissance mutuelle, double incrimination et territorialité. La reconnaissance mutuelle des décisions judiciaires pénales dans l'Union européene, p. 65-77, 2001. Disponível em: <http://hdl.handle.net/2268/79814>. Acesso em 18 mai. 2017. 
GLESS, Sabine. A Europa vista a partir de uma perspectiva alemã: um desafio para a defesa em processo penal. Revista Portuguesa de Ciência Criminal, Coimbra, v. 21, n. 3, p. 395-426., jul./set. 2011.

HAGGENMÜLLER, Sarah. The principle of proportionality and the European arrest warrant. Oñati Socio-legal Series [online], v. 3, n. 1, p. 95-106, 2013. Disponível em: <http://ssrn.com/abstract=2200874>. Acesso em 27 mai. 2017.

KLIP, André. European criminal Law. An integrative approach. Oxford: Intersentia, 2009.

KOSTORIS, Roberto E. Diritto europeo e giustizia penale: In: KOSTORIS, Roberto E. (a cura di). Manuale di procedura penale europea. Terza edizione. Milano: Giuffrè Editore, 2017. p. 1-76.

MIGUEL ZARAGOZA, Juan de. Algunas consideraciones sobre la Decisión Marco relativa a la orden de detención europea y a los procedimientos de entrega en la perspectiva de la extradición. Actualidad Penal, Madrid, v. 1, n. 4, p. 139-158., jan. 2003.

MITSILEGAS, Valsamis. EU criminal law. Oxford: Hart Publishing, 2009.

MORENO CATENA, Víctor. La orden europea de detención en España. Revista del Poder Judicial Madrid, n. 78, p. 11-38, 2005.

NIETO MARTÍN, Adán. Fundamentos constitucionales del sistema europeo de derecho penal. Direito e Cidadania, v. 7, n. 22, p. 27-89, 2005.

OLG STUTTGART. Beschl. v. 25.2.2010 - 1 Ausl. (24) 1246/09, BeckRS 2010, 6922.

PARLAMENTO EUROPEU. Carta dos direitos fundamentais da União Europeia. Jornal Oficial das Comunidades Europeias. C 364/01, 18.12.2000. Disponível em: <http://www.europarl.europa.eu/charter/pdf/text_pt.pdf>. Acesso em 25 mai. 2017.

PARLAMENTO EUROPEU. Conselho Europeu de Tampere, 15 e 16 de outubro de 1999: conclusões da presidência. 2010. Disponível em: <http://www.europarl. europa.eu/summits/tam_pt.htm>. Acesso em 17 mai. 2017.

PORTUGAL. DL n. ${ }^{\circ}$ 48/95, de 15 de Março: aprova o Código Penal. Disponível em: <http://www.pgdlisboa.pt/leis/lei_mostra_articulado.php?ficha=1\&artigo_id=\&nid=109\&pagina=1\&tabela=leis\&nversao=\&so_miolo=>. Acesso em 16 jan. 2018.

PORTUGAL. DL $n .^{\circ} 78 / 87$, de 17 de fevereiro: aprova o Código de Processo Penal. Revoga o Decreto-Lei n. ${ }^{\circ}$ 16489, de 15 de fevereiro de 1929. Disponível em: <http://www.pgdlisboa.pt/leis/lei_mostra_articulado.php?ficha= 
1\&artigo_id $=\&$ nid $=199 \&$ pagina $=1 \&$ tabela $=$ leis $\&$ nversao $=\&$ so_miolo $=>$. Acesso em 16 jan. 2018

RODRIGUES, Anabela Miranda. Comentários aos artigos $82^{\circ}$. a $84^{\circ}$. do Tratado de Lisboa. In: PORTO, Manuel Lopes; ANASTÁCIO, Gonçalo (coord.). Tratado de Lisboa: anotado e comentado. Coimbra: Almedina, 2002. p. 426-440.

RODRIGUES, Anabela Miranda. Globalização, crime e ciência penal “européia”. In: RODRIGUES, Anabela Miranda. O direito penal europeu emergente. Coimbra: Coimbra Editora, 2008. p. 361-384.

RODRIGUES, Anabela Miranda. Judicial cooperation in criminal matters, the principle of proportionality and the effectiveness of the European Arrest Warrant. Cahiers de defense sociale : bulletin de la Societé International de Défense Sociale pour une politique criminelle humaniste, Milano, n. 38, p. 82-90, 2013. Disponível em: <http://www.defensesociale.org/cahiers.htm>. Acesso em 11 jan. 2018.

RODRIGUES, Anabela Miranda. O direito penal europeu emergente. Coimbra: Coimbra Editora, 2008.

RODRIGUES, Anabela Miranda; MOTA, José Luís Lopes da. Para uma política criminal européia: quadro e instrumentos jurídicos da cooperação judiciária em matéria penal no espaço da União Europeia. Coimbra: Coimbra Editora, 2002.

SATZGER, Helmut. International and european criminal law. Oxford: Hart Publishing, 2012. https://doi.org/10.5771/9783845236186

SILVA SÁNCHEZ, Jesús-María. La expansión del derecho penal: aspectos de la política criminal en las sociedades postindustriales. 3. ed. Madrid: Edisofer S.L., 2011.

SILVA, Virgílio Afonso da. O proporcional e o razoável. Revista dos Tribunais, v. 91, n. 798, p. 23-50, abr. 2002.

SPENCER, John. Il principio del mutuo riconoscimento. In: KOSTORIS, Roberto E. (a cura di). Manuale di procedura penale europea. Terza edicione. Milano: Giuffrè Editore, 2017. p. 313-328.

TRIBUNAL DA RELAÇÃO DE COIMBRA. Acórdão 210/00.0TBTNV-A.C1. Relator: Jorge Gonçalves. Data: 21/11/2007. Disponível em: <http://www.dgsi.pt/jtrc.nsf/ c3fb530030ea1c61802568d9005cd5bb/2efa04e7488c8d62802573a700628f3b? OpenDocument\&Highlight=0, mandado,de,deten\%C3\%A7\%C3\%A3o,europeu>. Acesso em 27 mai. 2017. 
TRIBUNAL DA RELAÇÃO DE COIMBRA. Acórdão 585/05.5TATNV-A.C1. Relator: Calvário Antunes. Data: 05/05/2010. Disponível em: <http://www.dgsi.pt/jtrc. nsf/c3fb530030ea1c61802568d9005cd5bb/3ba4e4b6069be5bc8025772a0035606 c?OpenDocument\&Highlight=0,mandado,de,deten\%C3\%A7\%C3\%A3o,europeu>. Acesso em 18 jan. 2018.

TRIBUNAL DA RELAÇÃO DE LISBOA. Acórdão 546/17.1YRLSB5. Relator: Jorge Gonçalves. Data: 07/04/2017. Disponível em: <http://www.dgsi.pt/jtrl.nsf/ 33182fc732316039802565fa00497eec/96960c7c05dc8e108025813300466ba7 ?OpenDocument\&Highlight=0, mandado,de,deten\%C3\%A7\%C3\%A3o,europeu>. Acesso em 18 jan. 2017.

TRIBUNAL EUROPEU DOS DIREITOS DO HOMEM; COUNCIL OF EUROPE. Convenção europeia dos direitos do homem: com as modificações introduzidas pelos Protocolos n. 11 e 14, acompanhada do Protocolo adicional e dos Protocolos n. 4, 6, 7, 12 e 13. Disponível em: <http://www.echr.coe.int/Documents/Convention_POR.pdf $>$. Acesso em 28 mai. 2017.

UNIÃO EUROPEIA. Programa das medidas destinadas a aplicar o princípio do reconhecimento mútuo. Jornal oficial das Comunidades Europeias. C 12. Ano 44. 15.01.2001. Disponível em: <http://eur-lex.europa.eu/legal-content/PT/TXT/ HTML/?uri=CELEX:32001Y0115(02)\&qid=1494990147390\&from=EN >. Acesso em 17 mai. 2017.

UNIÃO EUROPEIA. Tratado de Lisboa: versão consolidada. Lisboa: Assembleia da República, 2008. Disponível em: <https://www.parlamento.pt/europa/Documents/Tratado_Versao_Consolidada.pdf>. Acesso em 17 mai. 2017.

VALENTE, Manuel Monteiro Guedes. Do mandado de detenção europeu. Coimbra: Almedina, 2006.

VERVAELE, John A. E. European Criminal Justice in the post-Lisbon area security and justice. Quaderni della facoltà di giurisprudenza, n. 5, Trento: Università Degli Studi di Trento, 2014.

VOGEL, Joachim. Cooperación penal: cinco tendencias. Cinco propuestas para una acción futura. In: ARROYO ZAPATERO, Luis. NIETO MARTIN, Adán. El derecho penal de la Unión Europea: situación actual y perspectivas de futuro. Cuenca. Ediciones de la Universidad de Castilla-La Mancha. 2007. p. 157-166.

WEYEMBERGH, Anne. European Added Value Assessment: The EU Arrest Warrant: Critical assessment of the existing European arrest warrant framework decision: Annex I. Brussels: European Parlament, 2014. Disponível em: <http:// 
www.europarl.europa.eu/RegData/etudes/etudes/join/2013/510979/IPOLJOIN_ET(2013)510979(ANN01)_EN.pdf>. Acesso em 25 mai. 2017.

WOLTER, Jürgen. Derechos humanos y protección de bienes jurídicos en un sistema europeo del derecho penal: In: SILVA SANCHÉZ, Jesús-María et. al. Fundamentos de un sistema europeo del derecho penal. Barcelona. José Maria Bosch Editor, 1995. p. 37-72.

\section{Informações adicionais e declarações dos autores (integridade científica)}

Declaração de conflito de interesses (conflict of interest declaration): o autor confirma que não há conflitos de interesse na realização das pesquisas expostas e na redação deste artigo.

Declaração de coautoria e especificação das contribuições (declaration of authorship): todas e somente as pessoas que atendem os requisitos de autoria deste artigo estão listadas como autores; todos os coautores se responsabilizam integralmente por este trabalho em sua totalidade.

Declaração de ineditismo e originalidade (declaration of originality): o autor assegura que o texto aqui publicado não foi divulgado anteriormente em outro meio e que futura republicação somente se realizará com a indicação expressa da referência desta publicação original; também atesta que não há plágio de terceiros ou autoplágio. 
Dados do processo editorial

(http://www.ibraspp.com.br/revista/index.php/RBDPP/about/editorialPolicies)

- Recebido em: 22/11/2017

Equipe editorial envolvida

- Controle preliminar e verificação de plágio: 27/11/2017

- Avaliação 1: 07/12/2017

- Avaliação 2: 16/12/2017

- Avaliação 3: 19/12/2017

- Decisão editorial preliminar: 08/01/2018

- Retorno rodada de correções 1: 24/01/2018

- Decisão editorial preliminar 2: 02/02/2018

- Retorno rodada de correções 2: 03/02/2018

- Decisão editorial final: 03/02/2018

\section{COMO CITAR ESTE ARTIGO:}

JANUÁRIO, Túlio Felippe Xavier. Do princípio da proporcionalidade e sua aplicação no mandado de detenção europeu. Revista Brasileira de Direito Processual Penal, Porto Alegre, vol. 4, n. 1, p. 435-472, jan./abr. 2018.

https://doi.org/10.22197/rbdpp.v4i1.114

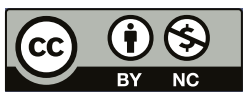

Esta obra está licenciada com uma Licença Creative Commons Atribuição-NãoComercial 4.0 Internacional. 